\title{
An Introduction to Indian Aesthetics: History, Theory, and Theoreticians by Mini Chandran and Sreenath V. S.
}

Bloomsbury India. 2021. pp. 2308, £76.50 / ISBN: 9789389165135

\author{
Prabha Shankar Dwivedi \\ Department of Humanities and Social Sciences, IIT Tirupati. \\ Email: prabhas.dwivedi@iittp.ac.in
}

This book can be seen as a response to a severe demand in the field of Indian poetics for an introductory book that provides an overview of all the seminal schools of Indian poetical thoughts, keeping in view both the theories and the theoreticians. This book, in the words of authors, is meant to be "An introduction to the world of Sanskrit poetics, explaining its major concepts lucidly for even those who do not know Sanskrit. It offers a comprehensive historical and conceptual overview of all the major schools in Sanskrit poetics.... It is meant to be a beginners' guide to the awe-inspiring immensity of Sanskrit literature and literary thought, the first step in a journey that should ideally lead to the profundities of ancient thought." (Chandran et al 2021, p. xii). The discussion in the book progresses with varied theoretical perspectives on Indian aesthetics in a well laid historico-conceptual order. Though the book briefly talks about Tamil poetics putting it parallel to Sanskrit poetics by comparing Tolkāppiyam with Nāțyaśāstra in the preface, it primarily serves to be an introductory handbook of Sanskrit poetics for the non-Sanskrit University students at various levels. This book succeeds in providing clearer idea of Indian poetical thoughts to its readers.

This book is primarily written from the perspective of a non-Sanskrit reader who studies Sanskrit with a puzzled head due to incomprehensible terms used in various translated texts, and the book successfully serves to the needs of such readers by providing them with simplified terms explicated aptly. Also, it is aimed at facilitating readers with the organised matters on the subject arranged in an order of evolution. The appendices of the book serve even a greater purpose of providing the readers with an untangled explanation of the generic division of Sanskrit literary traditions and categories of drama. The book contains eight chapters and two appendices that primarily support the stated goal of the book. The first chapter of the book deals with a historical and conceptual survey of Indian aesthetics. The book sees poetics under the broader rubric of aesthetics as the former is the study of the theory of literary forms and devices while the latter goes beyond it including the other art forms. In Indian context, aesthetics has primarily been concerned with poetry, music, and architecture, and therefore, it deals with the philosophic views of each of these known as - Rasa-Brahma Vāda, Nāda-Brahma Vãda, and Vāstu-Brahma Vãda (Pandey 1950, p. 1); the western approach in this regard is indistinct. In Indian knowledge tradition,

This Open Access article is published under a Creative Commons Attribution Non-Commercial 4.0 International License (http://creativecommons.org/licenses/by-nc/4.0/), which permits non-commercial re-use, distribution, and reproduction in any medium, provided the original work is properly cited. For citation use the DOI. For commercial re-use, please contact editor@rupkatha.com. 
poetry has been accorded the highest pedestal in all art forms, and drama is considered the highest among all forms of poetry; therefore, aesthetics as philosophy of fine art is studied from the beginning keeping in centre drama and poetry where music and scenic representations are seen as auxiliaries to it (Pandey 1950, p. 1). This book commences on a comparative note with a discussion on aesthetics and poetics from Aristotelian perspective, and then offers the reader with the Indian understanding of the terms. Indian aesthetics is believed to have begun with the conception of the theory of rasa in Nātyaśāstra which is considered as the first work on dramaturgy; while dramaturgy in sutra form had already been composed by Śilālin and Kṛ́așva, about which Pāninini mentions in his Asțādhyāȳ. The chapter approaches Nāțya and Kāvya separately, and discusses them under two different branches known as Nāțyaśāstra and Kā vyaśāstra. In a survey of the history of Kā vyaśāstra, the book takes along the Rāmāyana of Vālmīki and Vedic scriptures approaching their deontic functions from Abhinavagupta's point of view. Moving ahead with its distinctive approach, the book sees Bhāmaha's Kā vyālam kāra $\left(7^{\text {th }}\right.$ Century) as the earliest available text in Kā vyaśāstra. This chapter briefly discusses about the contributions of all other theoreticians whose conceptions shaped the face of poetics in India. It further offers an extracted definition of kāvya stating, "As we understand it today, is rather loosely defined as poetry. But we can use the term in a broader sense, where it encompasses all forms of literature like the mahā kāvya (long poem), the kathā (prose story) and other shorter verse forms. So Kā vyaśāstra would mean the science of literary composition." (Chandran et al 2021, p. 19). Surveying through all the six major schools and associated theoreticians of the Indian poetical thought, the first chapter successfully prepares a solid ground for the detailed discussion of six seminal theories of Indian poetics. This chapter also ensures the reader about the wide range of reading and research of the authors in the field before taking up this sort of writing that presents the highly philosophical propositions in the simplest possible manner.

The first chapter of the book serves as an introduction to the principal discussion of this book. The discussion in the second chapter is centred around the theory of rasa as propounded by Bharata in Nāțyaśāstra and discussed further by Bhațța Lollața, Sri Śankuka, Bhațța Nāyaka, and Abhinavagupta. rasa, a theory that is seen as a foundational postulation for the aesthetics, is the highest goal aimed at by any artist or composer. The discussion on this theory proceeds here chronologically, explaining all the aspects of rasanispatti. The book, unlike many other introductory texts, directly focuses on the major contentions of this theory in attempt to offer the readers with a rich discourse. The book approaches the theory of rasa from the perspective of an anumiti-vādi Sri Śankuka who refutes Lollața's contention of utpattivāda. The book shows the position of the theory of rasa in the monumental texts of Indian poetical tradition such as Dhvanyāloka, Hrdayadarpana, Abhinavabhārati, etc. In addition to a thorough discussion of the conception, the chapter offers a working example for the reader to understand the theory in clear terms. The concept of sahrdaya reader has also been well illustrated in the book with instances.

The subsequent chapters of the book are arranged in a logically graded sequence that serves to provide an answer to the same age-old question 'what constitutes literariness in kā vya' (Chandran et al 2021, p. 97) which all the schools of Indian poetics attempted to answer in their own ways. The third chapter of the book is centred on 'Alam kāra'. The alam kāra school of poetical thoughts holds a crucial position in Indian poetics, particularly, in Sanskrit literary tradition. The authors of the book consider 'figures of speech' or 'rhetoric' as English equivalents to the term 
alam kāra. The term is taken for analysis by the authors right from its etymology to its usage in the contemporary literary productions of Pablo Neruda and Bob Dylan. This chapter begins with a very basic understanding of the term but concludes with offering an advance understanding of the term by making the reader its application on the Indian as well as western pieces of writings. The critical perspective adopted in the book is of larger range where the authors commence the discussion with Bharata's take on alam kāras followed by number of theoreticians- like, Bhațti, Danḍin, Udbhațța, Vāmana, Rudrața, Vidyānātha, Jaydeva, Mammața, Udbhața, Kuntaka and Ānanadavardhana who preceded and succeeded the key exponent of this school Bhāmaha. The aforementioned theoreticians approached the question of 'literariness' from their perspectives and answered it according. Vāmana, after Bhāmaha and Danḍin, talks about the soul of poetry and states, 'ñtirātmā kāvyasya'. The English parallel used by the authors for $\bar{n} t i$ is diction, and they trace the history of this concept back in Bharata's Nāțyaśāstra where he talks about varied kinds of Vrttis. The book delineates this concept thoroughly in relation to gunas and doșas too. It throws light on the term 'mārga' too which is seen synonymous with it. The chapter also cites the excerpts relating to the discussion from V. K. Chari's Sanskrit Criticism. The fifth chapter of the book throws light on theory of dhvani. This theory primarily emerges from Sanskrit grammatical tradition, and later adopted by Ānandavardhana in the context of literariness of kā vya. The authors consider 'suggestion' or 'resonance' as equivalents to dhvani. The discussion in this chapter proceeds with the enunciation of conceptual foundations of this concept and its varied forms supported by the instances from both the traditions of knowledge- namely, Indian and Western. An illustration of the concept of Rasadhvani makes the discussion more fascinating as the authors cite the chosen instances from varied sources to make the readers enjoy the discussion for the spontaneous understanding of the conception. This chapter re-emphasises the role of a reader in appreciating a piece of poetry with textual citations from the Dhvanyāloka. Vakrokti is the subject of the sixth chapter of the book that is explained by the authors as 'deviant use of language'. This chapter takes up the discussion on this 'deviant utterance' (Chandran et al 2021, p. 124) from its historicoconceptual background referring to Bhāmaha who makes mention of this term for the first time in relation to poetry succeeded by Kuntaka who discusses it extensively in his Vakroktijivitam. The book further analyses the stand taken by Bhāmaha's immediate successor Danḍin whose discussion on vakrokti and svabhāvokti opens up a way for his successor Vāmana. Vāmana confines the scope of vakrokti to one of many Śabdālamkāras. Further, along with a discussion on opinions of Ratnākara, Rudrața, Ānandavardhana, Abhinavagupta, etc., the chapter implies a comparative perspective by putting forth the concept of defamiliarization of a Russian Formalist Viktor Shklovsky parallel to Kuntaka's delineation of the term. This chapter also comprises a detailed discussion with suitable instances on Kuntaka's six broad categories of vakratā. The seventh chapter of the book primarily focuses on Aucityavicāra of Kșemendra that is considered to be a foundational text of the theory of 'aucitya'. The English equivalent accepted by the authors for aucitya is propriety, and they see its association with the Greek term 'decorum'. This concept, unlike other conceptions, deals with all other aspects of a piece of poetry along with the literariness of the text. It focuses on all the three major aspects of a text- namely, language, form, and content that come together to enable the text in obtaining its goal that's 'rasa' or 'aesthetic relish'. The text proceeds with a detailed discussion on the evolution of the concept right from Bharata's Nāțaśāstra to 'chutnifying' of postcolonial writers like Salman Rushdie. The chapter 
consists of discussion sections on the functions of aucitya, diction in aucitya, and a Greek corresponding concept called 'decorum'.

The eighth chapter of the book is a summative discussion of the concepts discussed in the foregoing pages of the book, but the approach of the authors here again makes this discussion quite interesting for a reader who is also introduced to the western literary discourse. It enriches the reader by introducing another interesting tradition, i.e., the tradition of dissent and debate fostered in Indian knowledge system through various texts on purvapaksa and khandana or refutation- such as, Siddicandra's Kāvyaprakāśa-khaṇ̣̂ana, Jagannātha's Citramimām sakhandana, and various locanas that comprised serious dissents on the previously propounded concepts. This chapter of the book underlines a drastic change in the practice of dissent and debate after colonization by citing an appropriate excerpt from Sheldon Pollock's writing. It also throws light on the contemporary relevance of the ancient theories by citing apt instances from various related sources.

As mentioned earlier, the book also offers a comparative perspective to give the reader a clearer idea of the concepts as the modern terminologies and English equivalents have wider accessibility among readers that they come across frequently. Apart from eight chapters the book comprises two appendices. The first appendix is appended with an intention to enrich readers' understanding of Sanskrit literary tradition. It offers a brief but concrete explanation of the major genres prevalent in Sanskrit literary tradition throughout. The English parallels or explications of the Sanskrit terms chosen by the authors allow the readers to corelate them with matching terms in other tradition of knowledge and understand them further through the details offered. In case the reader wishes to know more about the terms, the authors have cited the authoritative texts and scholars where a thorough discussion on the term is available. This appendix not only offers an introductory note on the genres prevalent in Sanskrit poetry instead it throws equal light on the generic division of prose. The second appendix to the book presents a shortened version of the ten kinds of play that Bharata-Muni describes in the twentieth chapter of his Nātyaśāstra. The authors, to facilitate the reader's understanding of the categories, have explained the terms in abridged and lucid manner. The readers, who intend to know more details than offered here on the categories of Drama, can read the cited books that authors have kept in suggested readings. Bharata, in the twentieth chapter of the Nātyaśa $\bar{s} t r a$, discusses it in 150 verses, while the authors have summed up the whole idea in less than four pages. This certainly helps a beginner to understand all kinds of play discussed by Bharata with appropriate description and instances.

The book serves even a greater purpose of offering a much-needed comprehensive historico-conceptual overview of all the founding points of Sanskrit literary criticism with detailed discussion on the theories and theoreticians to those who might have not dared to understand and enjoy this literary tradition due to their non-Sanskrit background. Also, this book has potential to motivate students to pursue further studies in Indian as well as comparative poetics.

\section{Works Cited:}

Chandran, M., and Sreenath V. S. (2021). An Introduction to Indian Aesthetics: History, Theory and Theoreticians. Delhi: Bloomsbury.

Pandey, K. C. (1950). Comparative Aesthetics, vol. I: Indian Aesthetics. Chowkhamba Sanskrit Studies 2, Varanasi (reprint, 1995). 